\title{
Learning Organizations and Organizational Digital Competencies in the Field of Public Education
}

\author{
NÓRA FAZEKAS* \\ *Corvinus University of Budapest, Department of Management Control; \\ nora.fazekas@uni-corvinus.hu
}

DOI: $10.14267 / 978-963-503-867-1 \_03$

\begin{abstract}
In a constantly changing social, technological, and economic environment, schools not only need to adapt but to learn continuously. One of the most significant and most current fields of school learning in Hungary and worldwide is one of the digital competencies. In this paper, I present the concept of digital competencies and the learning organization, offering an overview of different interpretations and frameworks and draw connections between them. The study suggests interrelations between schools' learning organizational and digital competence capacities and proposes future empirical research on the topic.

Keywords: learning organization, organizational digital competence, school, educational institutions

Funding: The present publication is the outcome of the project "From Talent to Young Researcher project aimed at activities supporting the research career model in higher education," identifier EFOP-3.6.3-VEKOP-16-2017-00007 co-supported by the European Union, Hungary, and the European Social Fund.
\end{abstract}




\section{Introduction}

The rapid advancement of technology reshapes our environment. The ubiquity of digital technologies profoundly changes our lives and our learning processes (Redecker, 2017). More than that: we have to incorporate these into our everyday routines. Digital competence as one of the $21^{\text {st }}$-century skills (Tight, 2020) became essential in being relevant and connected in our knowledge society (Bindé, 2005). Accordingly, schools need to adapt to these new ways of learning and new forms of knowledge.

There has been much support coming from the European Committee's Joint Research Centre (JCR) in the past 15 years providing knowledge, frameworks, and measuring tools for supporting the improvement of digital competencies in the education system. The advancements in this area, as well as practices of educational institutions, can be informative for other sectors.

Working on becoming a learning organization (LO) might just naturally contribute to improving digital competencies as well. I will look at the two concepts in the theoretical background and then see how strengthening organizational learning capacities and building digital competencies are interrelated.

\section{Theoretical background}

\section{Digital Competences}

The concept of digital competencies in connection with carriers of digital technologies is also referred to as ICT (information and communication technologies) literacy and digital literacy in professional materials. There are no widely accepted definitions for these in the literature; terms like digital "skills," "competencies," "aptitudes," "knowledge," "understandings," "dispositions," and "thinking" are also frequently used (Atchoarena et al., 2017). The term digital competence is preferred in this study, as the concept of competence goes beyond the skills of interpretation and use implicated by literacy, comprehension, or thinking, as it includes elements of skill, knowledge, and attitude (Tót, 2017).

Digital competence can be broadly defined as the confident, critical, and creative use of ICT to achieve goals related to work, employability, learning, leisure, inclusion, and participation in society. Digitally competent educational organization refers to the effective use of digital technology by the educational organization and its staff to provide a compelling student experience and to realize a good return on investment in digital technology (Kampylis et al., 2015).

The European Commission's Joint Research Center (EC JRC) has been conducting research on learning in the digital age and related skills since 2005 (Carretero et al., 
2017). The European Digital Competence Framework, also known as DigComp, first appeared in 2013 as a reference for the development and strategic planning of digital competence initiatives. This standard was updated and expanded in 2016 (2.0) and then in 2017 (2.1). Building on this material, in 2015, the framework for educational organizations (DigCompOrg) and in 2017, the digital competence framework for educators (DigCompEdu) was created.

DigCompOrg (Kampylis et al., 2015) is a competence framework for educational institutions that works with seven thematic elements described by 74 indicators: (1) leadership and governance practices, (2) teaching and learning practices, (3) professional development, (4) assessment practices, (5) content and curricula, (6) collaboration and networking and (7) infrastructure. The framework also includes a sector-specific element to leave room for an adequate adaptation of the model.

The approach of DigCompOrg (Kampylis et al., 2015) suggests that the above elements are interconnected and interrelated and are parts of the same whole system. When discussing competence frameworks, the question of measurement rightfully comes forward. The EC JRC created an online tool for voluntary self-assessment based on DigCompOrg, called SELFIE (Self-reflection on Effective Learning by Fostering the Use of Innovative Educational Technologies) that is available in 24 official EU languages.

Complying with EU measures, the Hungarian education system has been taking strategic steps to improve digital competencies. Based on Hungary's Digital Education Strategy (Magyarország Digitális Oktatási Stratégiája, 2016) drown up in 2016, several digitization-related programs are implemented in public education in cooperation with the Educational Authority, the Digital Welfare Nonprofit Ltd. And the Károly Eszterházy University. The development project (EFOP-3.2.15 - VEKOP-17-201700001, Measurement-evaluation and digital developments related to the public education framework, development, and renewal of innovative educational organization procedures) was planned to terminate in October 2020.

Within the project' frame, the Digital Profile System (Digitális Névjegy Rendszer = DNR) for schools was created, based on DigCompOrg and DigCompEdu. DNR (DMPK, 2020) is a complex institutional feedback and development tool suitable for determining the level of digital maturity of schools. The use of the system helps the school to make the most out of digitization. The purpose of the system is multifaceted. It provides information on the digital maturity of the given public education institution and suggests possible development steps in a structured way. DNR also shows the stage of digital transition the school is at, while the system itself supports and reinforces the complex thinking of school actors about all areas of a digitally competent school. It supports the implementation of evidence-based decision-making of school leaders, maintainers, and policy institutions. DNR serves, however, neither qualification nor 
ranking purposes, nor does it replace a deep-reaching development process. The dimensions measured and assessed by DNR are 1) leadership and management practices, 2) digital pedagogical culture, 3) professional development, 4) school digital culture, 5) infrastructure.

\section{The learning organization}

Based on organizational learning theories, the concept of the learning organization offers a view that accepts that organizations, as entities, can learn and that this type of learning is more than the sum of individual learnings. These models provide focus areas for organizational development for the management. Several theoretical frameworks describe this ideal way of being of an organization.

The most fertile era of LO literature comes from the nineties, as a way of answering the calling of the new phenomena knowledge society and knowledge economy, emerging in academic discussion beforehand, in the eighties. If we look at five of the most influential scholarly definitions on the field (Table 1), also discussed by the Oxford Handbook of the Learning Organization (Örtenblad, 2019), we can identify some characteristics of mutual agreement, even though we can identify paradigmatic (Burrell \& Morgan, 1979) differences in the approach of the organization itself: the learning organization is conscious, goal-oriented, supports collective and open-system learning. Employees are empowered, the management is responsible for organizing the necessary structures and processes to nurture this practice and the culture of continuous improvement.

The concept of LO has been very popular with the education sector (Kools \& Stoll, 2016), probably due to the non-competition and non-profit orientation of the LO dimensions. Education management scholars and policy institutions have widely engaged with the model; becoming a LO is now part of the expectations towards educational institutions in the EU and Hungary as well (Okos köznevelés, 2015). In this study, we focus on developments on these two levels.

OECD defines the school as a learning organization (SLO) as an institution that "has the capacity to change and adapt routinely to new environments and circumstances as its members, individually and together, learn their way to realizing their vision" (Kools \& Stoll, 2016, p. 6). This approach aims to bridge related literature and concepts such as "professional learning communities" or "learning environments." Its dimensions are action-oriented, conveying a dynamic view of the LO that is receptive to the local and broader environment. The report emphasizes four transversal themes $(4 \mathrm{~T})$ that influence all LO dimensions: trust, time, technology, and thinking together. 
Table 1: Definitions of the learning organization

\begin{tabular}{|c|c|}
\hline LO scholar(s) & LO definition \\
\hline $\begin{array}{l}\text { Pedler et al. } \\
(1991, \text { p. } 1)\end{array}$ & $\begin{array}{l}\text { "An organization that facilitates the learning of all of its members and } \\
\text { continuously transforms itself to meet its strategic goals." }\end{array}$ \\
\hline $\begin{array}{l}\text { Senge } \\
(1993, \text { p. } 3)\end{array}$ & $\begin{array}{l}\text { "Where people continually expand their capacity to create the results } \\
\text { they truly desire, where new and expansive patterns of thinking are } \\
\text { nurtured, where collective aspiration is set free, and where people are } \\
\text { continuously learning to see the whole together." }\end{array}$ \\
\hline $\begin{array}{l}\text { Garvin } \\
(1993, \text { p. } 80) .\end{array}$ & $\begin{array}{l}\text { "An organization skilled at creating, acquiring, and transferring } \\
\text { knowledge, and at modifying its behavior to reflect new knowledge and } \\
\text { insights." }\end{array}$ \\
\hline $\begin{array}{l}\text { Watkins and Marsick } \\
(1996, \text { p. } 4)\end{array}$ & $\begin{array}{l}\text { "One that learns continuously and transforms itself. [...] Learning is a } \\
\text { continuous, strategically used process - integrated with and running } \\
\text { parallel to work." }\end{array}$ \\
\hline $\begin{array}{l}\text { Marquardt } \\
(2011, \text { p. } 247)\end{array}$ & $\begin{array}{l}\text { "A company that learns effectively and collectively and continually } \\
\text { transforms itself for better management and use of knowledge; empowers } \\
\text { people within and outside the organization to learn as they work; utilizes } \\
\text { technology to maximize learning and production." }\end{array}$ \\
\hline
\end{tabular}

Source: own compilation based on Pedler et al. 1991, Senge 1993, Garvin 1993, Watkins and Marsick 1996, Marquardt 2011

In a regional research project of the Hungarian-Netherlands School of Educational. Management (Hungarian abbreviation: KÖVI) (Baráth, 2017) the synchronousdiachronic (SD) LO model (see Figure 1) was designed to be suitable for taking a snapshot of the institutions at a given stage and at a given time in a synchronous manner, and for identifying the school's development path, focusing on evolutionary changes in a diachronic approach. In the center of the synchronous model stands learning and teaching, surrounded by supporting interrelated activity systems. Leadership appears as the outer circle, harmonizing efforts towards the core purpose. The progress of LO maturing is determined by human and organizational factors supporting the organization's learning capacity. 
Figure 1: The synchronous-diachronic model of the school as a learning organization

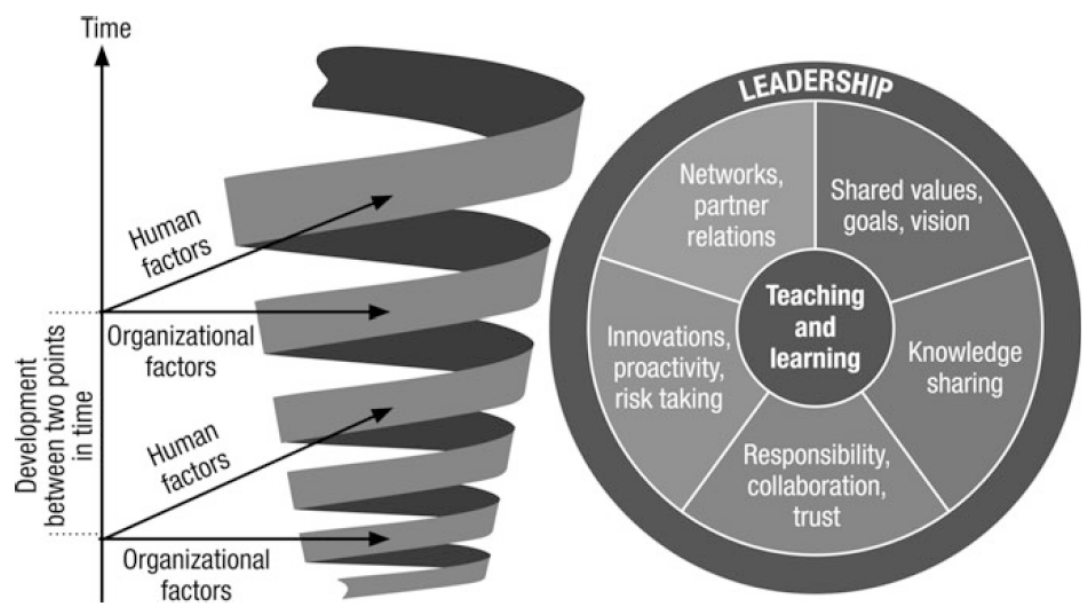

Source: Baráth, 2017 (p. 1189)

In Table 2, the introduced LO concepts' dimensions are displayed, grouped by topic. We can conclude that, as integrative models, the OECD and the Hungarian LO frameworks cover all the fields deemed necessary by former theorists to assess the LO capacity of school organizations. Both the OECD and the SD framework exclude technology as a separate dimension; however, OECD recognizes it as a transversal theme, and the SD model incorporates relevant aspects of digital competence in the sentence list of the measurement tool. Although system thinking as a distinct quality is missing from both models, the theoretical approach of the LO carries it immanently within. 
Table 2: Comparative analysis of learning organization concepts

\begin{tabular}{|c|c|c|c|c|c|}
\hline & Pedler et al. & Senge & Garvin & $\begin{array}{l}\text { Watkins \& } \\
\text { Marsick }\end{array}$ & Marquardt \\
\hline $\begin{array}{l}\text { Innovation, } \\
\text { transformation, } \\
\text { risk-taking }\end{array}$ & $\begin{array}{l}\text { Learning } \\
\text { climate }\end{array}$ & $\begin{array}{l}\text { Mental } \\
\text { models }\end{array}$ & Experimentation & $\begin{array}{l}\text { Inquiry and } \\
\text { dialogue }\end{array}$ & $\begin{array}{l}\text { Organization } \\
\text { transformation }\end{array}$ \\
\hline $\begin{array}{l}\text { Collective } \\
\text { learning, } \\
\text { knowledge } \\
\text { sharing }\end{array}$ & & $\begin{array}{l}\text { Team } \\
\text { learning }\end{array}$ & $\begin{array}{l}\text { Learning from } \\
\text { past experience } \\
\text { Transferring } \\
\text { knowledge }\end{array}$ & Team learning & $\begin{array}{c}\text { Learning } \\
\text { dynamics; } \\
\text { Knowledge } \\
\text { management }\end{array}$ \\
\hline $\begin{array}{l}\text { Common } \\
\text { vision, strategy }\end{array}$ & $\begin{array}{l}\text { Learning } \\
\text { approach to } \\
\text { strategy }\end{array}$ & $\begin{array}{l}\text { Building a } \\
\text { shared } \\
\text { vision }\end{array}$ & & Empowerment & \\
\hline $\begin{array}{l}\text { Individual } \\
\text { development, } \\
\text { empowerment }\end{array}$ & $\begin{array}{c}\text { Self- } \\
\text { development } \\
\text { for everyone }\end{array}$ & $\begin{array}{l}\text { Personal } \\
\text { mastery }\end{array}$ & & $\begin{array}{l}\text { Continuous } \\
\text { learning }\end{array}$ & $\begin{array}{c}\text { People } \\
\text { empowerment }\end{array}$ \\
\hline $\begin{array}{l}\text { Networking, } \\
\text { external } \\
\text { connections }\end{array}$ & $\begin{array}{c}\text { Boundary } \\
\text { workers as } \\
\text { environmental } \\
\text { scanners; } \\
\text { intercompany } \\
\text { learning }\end{array}$ & & $\begin{array}{l}\text { Learning from } \\
\text { others }\end{array}$ & $\begin{array}{c}\text { System } \\
\text { connection }\end{array}$ & \\
\hline $\begin{array}{l}\text { Processes and } \\
\text { structures }\end{array}$ & $\begin{array}{c}\text { Participative } \\
\text { policymaking; } \\
\text { Formative } \\
\text { accounting } \\
\text { and control; } \\
\text { Reward } \\
\text { flexibility; } \\
\text { Internal } \\
\text { exchange; } \\
\text { Enabling } \\
\text { structures }\end{array}$ & & $\begin{array}{c}\text { Systematic } \\
\text { problem solving }\end{array}$ & $\begin{array}{l}\text { Embedded } \\
\text { system }\end{array}$ & \\
\hline Leadership & & & & $\begin{array}{l}\text { Strategic } \\
\text { leadership }\end{array}$ & \\
\hline $\begin{array}{l}\text { Technology, } \\
\text { infrastructure }\end{array}$ & Information & & & & $\begin{array}{l}\text { Technology } \\
\text { application }\end{array}$ \\
\hline $\begin{array}{l}\text { System } \\
\text { thinking }\end{array}$ & & $\begin{array}{l}\text { System } \\
\text { thinking }\end{array}$ & & & \\
\hline
\end{tabular}




\begin{tabular}{|c|c|c|}
\hline & OECD & Baráth \\
\hline $\begin{array}{l}\text { Innovation, } \\
\text { transformation, } \\
\text { risk-taking }\end{array}$ & $\begin{array}{l}\text { Establishing a culture of inquiry, } \\
\text { exploration, and innovation }\end{array}$ & Innovations, proactivity, risk-taking \\
\hline $\begin{array}{l}\text { Collective } \\
\text { learning, } \\
\text { knowledge } \\
\text { sharing }\end{array}$ & $\begin{array}{l}\text { Promoting team learning and } \\
\text { collaboration among all staff }\end{array}$ & Knowledge sharing \\
\hline $\begin{array}{l}\text { Common } \\
\text { vision, strategy }\end{array}$ & $\begin{array}{l}\text { Developing a shared vision centered on } \\
\text { the learning of all students }\end{array}$ & Shared values, goals, vision \\
\hline $\begin{array}{l}\text { Individual } \\
\text { development, } \\
\text { empowerment }\end{array}$ & $\begin{array}{l}\text { Creating and supporting continuous } \\
\text { professional learning for all staff }\end{array}$ & \\
\hline $\begin{array}{l}\text { Networking, } \\
\text { external } \\
\text { connections }\end{array}$ & $\begin{array}{l}\text { Learning with and from the external } \\
\text { environment and more extensive } \\
\text { system }\end{array}$ & Networks, partner relations \\
\hline $\begin{array}{l}\text { Processes and } \\
\text { structures }\end{array}$ & $\begin{array}{l}\text { Embedding systems for collecting and } \\
\text { exchanging knowledge and learning }\end{array}$ & $\begin{array}{l}\text { Responsibility, collaboration, trust; } \\
\text { Teaching and learning }\end{array}$ \\
\hline Leadership & $\begin{array}{c}\text { Modeling and growing learning } \\
\text { leadership }\end{array}$ & Leadership \\
\hline $\begin{array}{l}\text { Technology, } \\
\text { infrastructure }\end{array}$ & & \\
\hline $\begin{array}{l}\text { System } \\
\text { thinking }\end{array}$ & & \\
\hline
\end{tabular}

Source: own editing 


\section{Methods}

The previous section has provided a brief overview of organizational digital competence frameworks and a comparative analysis about learning organization concepts through a narrative literature review (Cronin \& Coughlan, 2008). This type of review enables a comprehensive and critical analysis of current knowledge in the chosen field with the purpose to identify patterns and trends in academic discourse, pointing to gaps and inconsistencies to explore.

\section{Results}

In this section, the interrelations of LO maturity and digital competencies are presented: how do schools' capabilities on these two fields impact each other? To answer this question, we will focus on the introduced Hungarian models of the LO and digital competencies.

\section{How can becoming a learning organization contribute to the school's digital competencies?}

Improving school practices in the dimension of shared values, goals, vision help to create a shared understanding about the role of digital competencies within the school, and to set goals that fit external expectations and at the same time agree with teachers' needs, fears, and technology readiness as well. It allows to shape teachers' attitudes and commitment towards digitalization and to create a welcoming culture both in pedagogical and organizational areas.

Fostering learning leadership, systems of teacher and student evaluation, knowledge sharing and professional development, communication, and relations with internal and external stakeholders, as well as infrastructure management, can become more strategically organized to reach digitalization goals. By developing knowledge-sharing processes and systems, digital innovations and experiences with digital materials or tools can be spread more efficiently within the school. Moreover, if adequate processes, systems, and spaces of knowledge sharing are established, learning in all fields can be accelerated.

Strengthening the culture of innovation, proactivity, and risk-taking will allow school managers and teachers to look for the best digital solutions and empower them to experiment, contributing to pedagogical and organizational renewal and enhancing the school's competitiveness. Building a responsible, collaborative and trustful school community empowers teachers to progress with digital initiatives in a joint, collective 
effort. It cultivates sharing of digital materials, starting new cooperation within and outside of school. It enables responsible ICT and internet usage in the handling of school and personal devices. Building and taking care of network and partner relations helps the school to bring in new digital knowledge and asses its stakeholders' needs of educational service that can or have to be supported via digital solutions.

If teaching and learning are in focus, and the school has its vision about what to provide its stakeholders, it is determined to find and create those kinds of digital assistance that help to realize that vision.

\section{How can a higher level of digital organizational competencies contribute to becoming a $L O$ ?}

Supporting leadership and management processes with digitalization provides the opportunity for school management to make information-based pedagogical, organizational, and operational decisions. It helps to set goals, plan actions and monitor them throughout the process. It helps to create additional platforms of knowledge sharing and knowledge building. Using digital and online platforms for information sharing supports more transparent operations, builds channels of external and network contacts while increasing their quality.

Improving digital pedagogical culture, the possibilities to involve a greater variety of materials and contents grows immensely. It can also enable cross-subject or even crossschool collaborations by establishing the necessary infrastructures. If pedagogical administration is well integrated with school software, learning paths can be monitored that support personalized education.

Digital professional development can raise teachers' engagement with the development of students' learning by new technologies and improve teachers' participation in organizational processes that involve digital platforms. Continuous self-development on the field helps to keep the school up to date too. If the school established in-house digital learning for teachers, like training or mentoring, it could foster community building and a culture of knowledge-sharing. With its growing knowledge, the school can serve as a role model and connect with other schools.

A high level of digital school culture improves the communication flow of the school, and with steady digital cultural and digital ethics knowledge, digital platforms can become secure and trustful environments that nurture collaboration and joint learning of the school staff. 
Infrastructure, if planned and run wisely, will provide the basis for all the internal and external collaboration, access to information and learning, connecting personal and professional spheres of students', parents', and teachers' lives. The proper infrastructure can also help to compensate for missing learning environments and expand it to a global learning room for both staff and students.

\section{Discussion and recommendations}

In this paper, I presented the two concepts of digital organizational competencies and the school as a learning organization. I have introduced definitions and interpretations of digital competence, as well as international and Hungarian progress in addressing and measuring it. I gave an overview about the concept of the learning organization, demonstrated by a comparative analysis, arriving at the model of school as a learning organization. Based on the common approaches of the frameworks, I set out to connect these concepts and suggest explanations, how the two types of organizational capacities can support each other.

In conclusion, research is suggested to test and prove the strength and direction of the causal relationships among the dimensions of a chosen digital competence framework and a learning organization model to identify the most impactful intervention points for organizational improvement. The proposed research can inform school management not

only with practical and tangible knowledge but involve specifics of the education sector as well.

\section{References}

Atchoarena, D., Selwyn, N., Chakroun, B., Miao, F. West, \& M., Coligny, C. (2017). Working Group on Education: Digital skills for life and work. Geneva Switzerland, Broadband Commission for Sustainable Development

Baráth, T. (2017). Leading Learning Schools, In Advances in Human Factors, In Kantola, J.I., Barath, T., Nazir, S., Andre, T. (Eds.) Business Management, Training, and Education (pp. 1185-1198). Springer, Cham.

Bindé, J. (2005) Towards knowledge societies: UNESCO world report. PDF file. Online: from https://unesdoc.unesco.org/ark:/48223/pf0000141843. Downloaded: 2020.01.09.

Burrell, G., \& Morgan, G. (1979). Sociological paradigms and organisational analysis: Elements of the sociology of corporate life. Routledge.

DPMK (2020). A Digitális Iskola Kézikönyve [Handbook of the Digital School]. Retrieved January 25, 2021, from https://dnr.dpmk.hu/static/manual/dnr_kezikonyv.pdf 
Carretero, S., Vuorikari, R., \& Punie, Y. (2017). DigComp 2.1: The Digital Competence Framework for Citizens with eight proficiency levels and examples of use (No. JRC106281). Joint Research Centre (Seville site)

Cronin, P., Ryan, F., \& Coughlan, M. (2008). Undertaking a literature review: a step-by-step approach. British Journal of Nursing, 17(1), 38-43.

Garvin, D. A. (1993). Building a Learning Organization. Harvard Business Review, July-August, 78-91.

Kampylis, P., Punie, Y., \& Devine, J. (2015). Promoting effective digital-age learning-A European framework for digitally-competent educational organisations (No. JRC98209). Joint Research Centre (Seville site).

Kools, M., \& Stoll L. (2016). What Makes a School a Learning Organisation? OECD Education Working Papers, No. 137, OECD Publishing, Paris. http://dx.doi.org/10.1787/5jlwm62b3bvh-en

Magyarország Digitális Oktatási Stratégiája [The Digital Education Strategy of Hungary] (2016), Digitális Jólét Program. Retrieved February 18, 2021, from https://digitalisjoletprogram.hu/files/55/8c/558c2bb47626ccb966050debb69f600e.pdf

Marquardt, M. J. (2011). Building the learning organization: mastering the five elements for corporate learning. Hachette Book Group.

Okos Köznevelés: Javaslat a Nemzeti Oktatási Innovációs Rendszer stratégiájának kiegészítéséz, „NOIR+ Stratégia” [Smart Public Education: Suggestions for the National Education Innovation System strategy, „NOIR + Strategy”] (2015), Halász Gábor. Retrieved April 23, 2019, from http://halaszg.ofi.hu/download/A_NOIR_plusz_(2015.07.26)

Örtenblad, A. (Ed.). (2019). The Oxford Handbook of the Learning Organization. Oxford University Press.

Pedler, M., Burgoyne, J. G., \& Boydell, T. (1991). The learning company: a strategy for sustainable development. McGraw-Hill.

Senge, P. M. (1990). The fifth discipline. The art and practice of the learning organization. Doubleday.

Tight, M. (2020). Twenty-first century skills: meaning, usage and value. European Journal of Higher Education, 1-15. https://doi.org/10.1080/21568235.2020.1835517

Tót, É. (2017). Segédlet a tanulási eredmények írásához a felsőoktatási szektor számára [A guide to writing learning outcomes for the higher education sector]; Oktatási Hivatal, Retrieved April 4, 2018, from https://www.oktatas.hu/pub_bin/dload/LLL/ekkr/Tanulasieredmenyek_HE.pdf Watkins, K. E., \& Marsick, V. J. (1996). In action. Creating the Learning Organization. Alexandria VA: American Society for Training and Development. 